\title{
Applicability of Moringa oleifera Lam. pie as an adsorbent for removal of heavy metals from waters
}

\author{
Affonso C. Gonçalves Junior ${ }^{1}$, Ana P. Meneghel' ${ }^{1}$, Fernanda Rubio', \\ Leonardo Strey ${ }^{1}$, Douglas C. Dragunski ${ }^{2}$ \& Gustavo F. Coelho'
}

\begin{abstract}
This study evaluated the efficacy of moringa seeds (Moringa oleifera Lam.) as an adsorbent material for removing toxic heavy metals such as cadmium, lead, and chromium from contaminated solutions. The effect of the adsorbent mass was investigated at two $\mathrm{pH}$ conditions (5.0 and 7.0). The optimized conditions were $0.300 \mathrm{~g}$ of adsorbent at $\mathrm{pH} 5.0$, used for the isotherms construction, and linearized according to Langmuir and Freundlich models. Results showed that cadmium adsorption was similar in both the models used. For lead, the Freundlich model had the best adjustment and chromium was better adjusted by the Langmuir model. It was concluded that the adsorbent was effective in the remediation of solutions containing cadmium, lead and chromium, thus, its use as sustainable alternative material is feasible, since it has low cost, does not need a previous treatment and it is a byproduct.
\end{abstract}

Key words: adsorption, isotherms, remediation

\section{Aplicabilidade da torta de Moringa oleifera Lam. como adsorvente para remoção de metais pesados de águas}

\section{RESUMO}

Este estudo objetivou avaliar a eficácia do uso da torta de moringa (Moringa oleifera Lam.) como material adsorvente dos metais pesados tóxicos cádmio $(\mathrm{Cd})$, chumbo $(\mathrm{Pb})$ e cromo $(\mathrm{Cr})$ de soluções contaminadas. Nos testes cinéticos foram variadas as massas do adsorvente em duas condições de $\mathrm{pH}(5,0$ e 7,0$)$. As condições otimizadas foram $\mathrm{pH}$ 5,0 e massa de $0.300 \mathrm{~g}$ de adsorvente, utilizados para a construção das isotermas e linearizadas conforme os modelos de Langmuir e Freundlich. Realizou-se a determinação dos metais por espectrometria de absorção atômica. Os resultados mostraram que houve semelhança em ambos os modelos utilizados para a adsorção do $\mathrm{Cd}$. Para o $\mathrm{Pb}$, o modelo de Freundlich apresentou o melhor ajuste e, para o $\mathrm{Cr}$, houve melhor ajuste pelo modelo de Langmuir. Conclui-se, com base nos resultados obtidos, que o adsorvente foi eficaz na remediação de soluções contendo $\mathrm{Cd}$, $\mathrm{Pb}$ e $\mathrm{Cr}$ e, assim, é viável a utilização desse adsorvente como material alternativo sustentável, pois apresenta baixo custo, não necessita de tratamento prévio e se trata de um coproduto.

Palavras-chave: adsorção, isotermas, remediação 


\section{INTRODUCTION}

A major problem today is the environmental pollution coming largely from the improper management of pesticides, lowquality water used in the irrigation process and indiscriminate disposal of industrial or domestic waste, which may cause the accumulation of substances that can be toxic to plants and may become dangerous to animals and human beings if they come in the food chain (Camargo et al., 2006).

The water contamination by heavy metals has been a major concern for researchers and government agencies involved with the pollution control (Oliveira et al., 2001), mainly by toxic heavy metals, harmful contaminants due to their ability of retaining and accumulating in the human body (Reddy et al., 2010).

Some metals are used in the biological metabolism and thus may be considered essential, such as copper $(\mathrm{Cu})$, zinc $(\mathrm{Zn})$, nickel $(\mathrm{Ni})$ and chromium $(\mathrm{Cr})$, which at higher concentrations can become toxic. However, lead $(\mathrm{Pb})$ and cadmium $(\mathrm{Cd})$ are considered toxic even at trace levels (Gonçalves et al., 2009).

An efficient remediation alternative of natural resources contaminated with toxic heavy metals is the adsorption process, which can regulate the mobility and bioavailability of pollutants in solution (Araújo et al., 2002).

The removal of heavy metals from effluents involving adsorption on organic and inorganic materials may be a quite interesting option, mainly because they are available in large amounts and at low costs (Kumar et al., 2000). Moreover, the process has other advantages such as no need for any pretreatment of material, high efficiency and the possibility of recovery of metal adsorbed (Reddy et al., 2010).

Considering the features and advantages attributed to the biological adsorption process, it is fundamental to make attempts to find new technically and economically feasible adsorbent materials (Santos et al., 2010b).

Thus, some biological adsorbents, or biosorbents, such as sugarcane bagasse in the removal of $\mathrm{Pb}$ (Santos et al., 2010b) and $\mathrm{Cr}$ (Santos et al., 2010a), mussel shells (Peña-Rodríguez et al., 2010) and dry biomass of Eichornia crassipes (Gonçalves $\mathrm{Jr}$. et al., 2009) have been explored, regard to the removal of heavy metals in solution.

Considering various species of plants tested around the world, some of them showed a great ability to clarify natural waters containing impurities. One of these species is Moringa oleifera Lam., belonging to Moringaceae (Katayon et al., 2006), which, in addition to the clarifying property, has other attractive features, such as high nutritional value and an oil content, between 27 and 40\% (Jahn, 1989). This crop emerged in certain regions as an alternative and a good choice for biodiesel production, mainly by adapting to various climatic conditions, having a good tolerance to drought and high availability throughout the year (Sharma et al., 2006).

Most studies related to metals adsorption using different adsorbent materials has been conducted only in monoelementary solutions. However, it is well known that many metals are found simultaneously in effluents, so it is necessary to make studies involving two or more metals in aqueous solutions (Srivastava et al., 2008), Considering the advantages attributed to moringa, the present work aimed to study the reuse of the byproduct from its seeds for the adsorption and removal of heavy metals $\mathrm{Cd}$, $\mathrm{Pb}$ and $\mathrm{Cr}$, present in contaminated solutions.

\section{MATERIAL AND METHODS}

The experiment was carried out at the Laboratory of Environmental and Instrumental Chemistry, Center of Agricultural Sciences, West Paraná State University, Campus Marechal Cândido Rondon, PR, Brazil.

Moringa seeds obtained at Uberlândia, MG, Brazil, were crushed and dried in an oven at $60{ }^{\circ} \mathrm{C}$ for $36 \mathrm{~h}$. Subsequently, the seed oil was extracted through a Soxhlet system (IUPAC, 1988) resulting in the byproduct, which was dried again in the oven at $60{ }^{\circ} \mathrm{C}$ for $24 \mathrm{~h}$, for complete evaporation of n-hexane used for the oil extraction.

A fraction of the moringa byproduct was submitted to nitropercloric digestion (AOAC, 2005), for determining the concentrations of $\mathrm{Cd}, \mathrm{Pb}$ and $\mathrm{Cr}$ by atomic absorption spectrometry - flame (FAAS) (GBG 932 AA) (Welz \& Sperling, 1999).

The procedure for determining the $\mathrm{pH}_{\mathrm{PCZ}}$ consisted of performing a mixture of $50 \mathrm{mg}$ of the adsorbent in $50 \mathrm{~mL}$ aqueous $\mathrm{KCl}$ at two concentrations $\left(0.05\right.$ and $\left.0.5 \mathrm{~mol} \mathrm{~L}^{-1}\right)$, with initial $\mathrm{pH}$ values ranging from 2.0 to 10.0 , which were buffered with solutions of $\mathrm{HCl}$ and $\mathrm{NaOH}\left(0.01 \mathrm{~mol} \mathrm{~L}^{-1}\right)$. After the contact for $24 \mathrm{~h}$, the final $\mathrm{pH}$ values were obtained and plotted on a graph correlating the variation of initial and final $\mathrm{pH}$, with $\mathrm{pH}_{\mathrm{PZC}}$ corresponding to the range in which the final $\mathrm{pH}$ is kept constant (regardless of the initial $\mathrm{pH}$ ), i.e., the adsorbent surface behaves as a buffer (Mimura et al., 2010).

Aqueous solutions $(1000 \mathrm{~mL})$ fortified with $\mathrm{Cd}, \mathrm{Pb}$ and $\mathrm{Cr}$ were prepared and obtained from an aliquot of the stock standard solution $\left(100 \mu \mathrm{g} \mathrm{mL}^{-1}\right)$.

The tests ranging the mass were carried out to verify the ideal adsorption conditions, using increasing amounts of adsorbent material ( 0.0 to $0.900 \mathrm{~g}$ ) at two $\mathrm{pH}$ conditions (5.0 and 7.0), adjusted and buffered with standard solutions of $\mathrm{HCl}$ and $\mathrm{NaOH}\left(0.100 \mathrm{~mol} \mathrm{~L}^{-1}\right)$.

In Erlenmeyer flask $(125 \mathrm{~mL})$ containing the adsorbent material were added $50 \mathrm{~mL}$ of aqueous solution enriched with heavy metals in the following concentrations: $\mathrm{Cd}$ (0.05 mg mL $\left.{ }^{-1}\right), \mathrm{Pb}\left(0.10 \mathrm{mg} \mathrm{mL}^{-1}\right), \mathrm{Cr}\left(0.50 \mathrm{mg} \mathrm{m}^{-1}\right)$. The concentration chosen for each metal studied in this stage was 10 times the maximum allowed value in accordance with Ordinance № 518 from the Brazilian Health Ministry, which establishes procedures and responsibilities relating to control and surveillance of water quality for human drinking and its potability standards (Brasil, 2004).

The flasks were shaken for $90 \mathrm{~min}$ at constant temperature and stirring $\left(25^{\circ} \mathrm{C}\right.$ and $\left.200 \mathrm{rpm}\right)$ in thermostat water bath, and then $10 \mathrm{~mL}$ aliquots were centrifuged for $5 \mathrm{~min}$ at $3000 \mathrm{RPM}$, in order to separate the adsorbent from the aqueous solution, and subsequently to determine the concentrations of $\mathrm{Cd}, \mathrm{Pb}$ and $\mathrm{Cr}$ in the solution by FAAS (Welz \& Sperling, 1999).

The isotherms were obtained based on the optimum conditions established previously in the mass and $\mathrm{pH}$ tests. Therefore, $0.300 \mathrm{~g}$ of moringa seeds byproduct were added 
to Erlenmeyer flasks $(125 \mathrm{~mL})$ with a solution enriched with increasing concentrations of the toxic heavy metals studied. For this, an adjusted and buffered solution at pH 5.0, was used containing the following metal concentrations: $\mathrm{Cd}\left(0.20 \mu \mathrm{g} \mathrm{mL}^{-1}\right)$, $\mathrm{Pb}\left(0.40 \mu \mathrm{g} \mathrm{mL}^{-1}\right), \mathrm{Cr}\left(2.0 \mu \mathrm{g} \mathrm{mL}^{-1}\right)$, values that correspond to 40 times the maximum allowed value by the Ordinance n. 518 MS (Brasil, 2004).

The flasks were shaken at 200 RPM in water bath maintained at $25^{\circ} \mathrm{C}$ for $90 \mathrm{~min}$. Subsequently, aliquots of this solution were centrifuged for $5 \mathrm{~min}$ at $3000 \mathrm{RPM}$, to separate the adsorbent from the aqueous solution. Then, the content of metal in the solutions by FAAS (Welz \& Sperling, 1999) was determined using the Eq. 1:

$$
\mathrm{Q}_{\mathrm{eq}}=\frac{\left(\mathrm{C}_{0}-\mathrm{C}_{\mathrm{eq}}\right)}{\mathrm{m}} \mathrm{V}
$$

where:

$\mathrm{Q}_{\mathrm{eq}} \quad$ - amount of metal adsorbed, $\mathrm{mg} \mathrm{g}^{-1}$

$\mathrm{m}$ - mass of adsorbent used, $\mathrm{g}$

$\mathrm{C}_{0}$ - initial concentration of metal in solution, $\mathrm{mg} \mathrm{L}^{-1}$ $\mathrm{mg} \mathrm{L}^{-1}$

$\mathrm{C}_{\mathrm{eq}}$ - metal concentration at equilibrium in the solution,

V - volume of solution used, L

The percentage of metal removal (R\%) from solution was calculated according to Eq. 2:

$$
\% \mathrm{R}=100-\left(\frac{\mathrm{C}_{\mathrm{eq}}}{\mathrm{C}_{0}} \times 100\right)
$$

where:

$\% \mathrm{R}$ - metal removal (\%) from solution by the seed byproduct of Moringa oleifera Lam. $\mathrm{mg} \mathrm{L}^{-1}$

$\mathrm{C}_{\text {eq }}$ - metal concentration at equilibrium in the solution,

$\mathrm{C}_{0}$ - initial metal concentration in the solution, $\mathrm{mg} \mathrm{L}^{-1}$

The linearization of isotherms was carried out using the mathematical models of Langmuir (Eq. 3) and Freundlich (Eq. 4):

$$
\frac{\mathrm{C}_{\mathrm{eq}}}{\mathrm{Q}_{\mathrm{eq}}}=\frac{1}{\mathrm{Q}_{\mathrm{m}} \mathrm{b}}+\frac{\mathrm{C}_{\mathrm{eq}}}{\mathrm{Q}_{\mathrm{m}}}
$$

where:

$$
\mathrm{mg} \mathrm{L}^{-1}
$$

$\mathrm{C}_{\mathrm{eq}}$ - metal concentration at equilibrium in the solution,

$\mathrm{Q}_{\mathrm{eq}}$ - amount adsorbed at the equilibrium per adsorbent unit mass, $\mathrm{mg} \mathrm{g}^{-1}$

$\mathrm{Q}_{\mathrm{m}} \quad$ - maximum adsorption capacity, $\mathrm{mg} \mathrm{g}^{-1}$

$\mathrm{b}$ - parameter related to strength of the adsorbateadsorbent interaction

$$
\log \mathrm{Q}_{\mathrm{eq}}=\log \mathrm{K}_{\mathrm{f}}+\frac{1}{\mathrm{n}} \log \mathrm{C}_{\mathrm{eq}}
$$

where:

$\mathrm{C}_{\mathrm{eq}}$ - metal concentration at equilibrium in solution, $\mathrm{mg} \mathrm{L}^{-1}$

$\mathrm{Q}_{\mathrm{eq}}$ - amount adsorbed at equilibrium per adsorbent unit mass, $\mathrm{mg} \mathrm{g}^{-1}$

$\mathrm{K}_{\mathrm{f}}$ and $\mathrm{n}$ - related to the adsorption capacity and the heterogeneity of the solid, respectively

\section{RESULTS AND DISCUSSION}

The results of determination of toxic heavy metals in the moringa byproduct were $1.00 \mu \mathrm{g} \mathrm{Cd} \mathrm{g}^{-1}, 3.93 \mu \mathrm{g} \mathrm{Pb} \mathrm{g}{ }^{-1}$ and $0.37 \mu \mathrm{g} \mathrm{Cr} \mathrm{g}^{-1}$.

The presence of from soil heavy metals in plants and seeds is due to absorption from soil or absorption via the application of pesticides or fertilizers, since the fertilizers used to supply micronutrients have toxic heavy metals such as $\mathrm{Cd}, \mathrm{Pb}$ and $\mathrm{Cr}$ in their composition, in addition to the desirable elements (Gonçalves Jr. \& Pessoa, 2002). These heavy metals may come from indiscriminate disposal of industrial waste, which contain micronutrients and are sold as fertilizers (Gonçalves Jr. et al., 2000).

Thus, knowing the possibility of inputs application in the moringa crop, the presence of these elements in the byproduct can be justified by the use of these practices.

In order to understand the adsorption mechanism, it is necessary to determine the zero charge point $\left(\mathrm{pH}_{\mathrm{PZC}}\right)$ of the adsorbent (Wang et al., 2008). The results obtained in $\mathrm{KCl}$ solutions indicated that the zero charge point for moringa is about $\mathrm{pH} 4.4$ (Figure 1). Thus, the adsorption of cations in case of heavy metals is favored at $\mathrm{pH}$ values above the $\mathrm{pH}_{\mathrm{PZC}}$ (Tagliaferro et al., 2011).

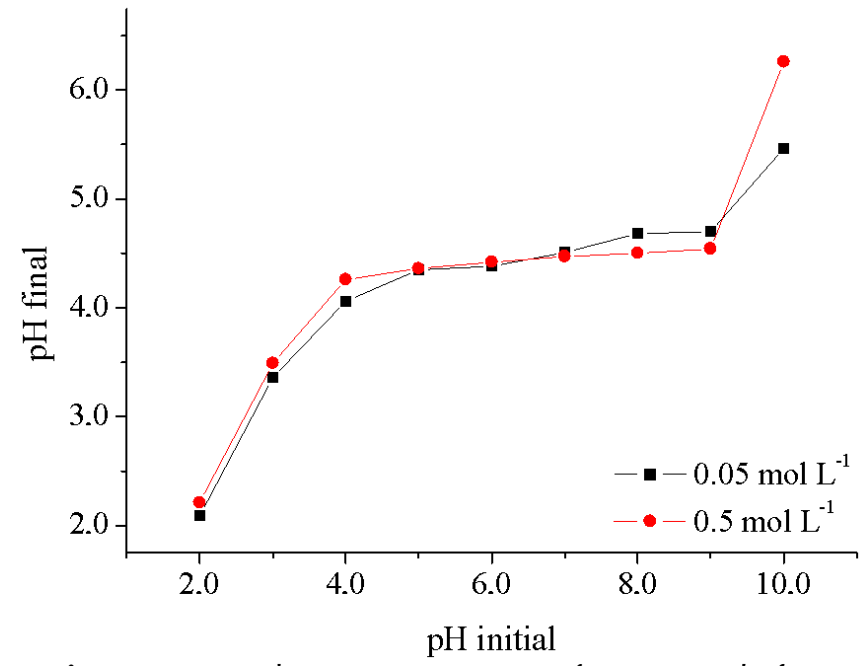

Figure 1. Zero charge point $\left(\mathrm{pH}_{\mathrm{PCZ}}\right)$ of Moringa oleifera Lam

The $\mathrm{pH}$ chosen was $\mathrm{pH} 5.0$ for solutions in subsequent tests, because, in addition to the $\mathrm{pH}_{\mathrm{PZC}}$ test, it was also possible to prove in the $\mathrm{pH}$ test that fortified solutions at $\mathrm{pH} 5.0$ needed lower mass to achieve a similar efficiency to that obtained under conditions of $\mathrm{pH}$ 7.0. One important factor is that lower $\mathrm{pH}$ values keep the metal soluble and favor its mobility (Fetter, 1993), confirming the data reported by Sud et al. (2008), whose 
metals as $\mathrm{Cd}$ and $\mathrm{Pb}$ the optimum $\mathrm{pH}$ values for adsorption using agricultural residues are that with acidic character.

The metal removal efficiency increased with the mass increase, a fact that can be attributed to the increased surface area for adsorption and to the availability of active adsorption sites. However, an excessive increase in the adsorbent amount may cause a reduction in the removal, may be due to the formation of aggregates during sorption, as described by Ekmekyapar et al. (2006). Thus, the mass chosen for the procedure was $0.300 \mathrm{~g}$.

The adsorption isotherms of the studied metals on the moringa byproduct were based on the best results obtained in the tests: $0.300 \mathrm{~g}$ of adsorbent and solution at pH 5.0 (Figure 2).

The mean percentage of removal from solution by the adsorbent was $80.2 \%$ for $\mathrm{Cd}, 69.2 \%$ for $\mathrm{Pb}$, and $86.7 \%$ for $\mathrm{Cr}$. After the isotherms construction, the linearization was performed according to the mathematical models of Langmuir and Freundlich, using the aforementioned Eqs. 3 and 4, respectively.

Table 1 shows the parameters obtained and their correlation coefficients for linear fit of adsorption data according to Langmuir and Freundlich models.

The experimental data of $\mathrm{Cd}$ adsorption on the moringa byproduct were similar in both the models used, since the difference between determination coefficients $\left(\mathrm{R}^{2}\right)$ was negligible, indicating a possible existence of more than one type of adsorption site interacting with the metal. For $\mathrm{Pb}$, the model that best fitted was Freundlich, indicating that the adsorption occurred in multiple layers (Tarley \& Arruda, 2003). Linearization data showed the best fit by Langmuir model for $\mathrm{Cr}$, which shows higher monolayer adsorption.

Values of Freundlich constants $\left(\mathrm{K}_{\mathrm{f}}\right)$ for $\mathrm{Cd}, \mathrm{Pb}$ and $\mathrm{Cr}$ on the adsorbent ranged from 0.187 to $9.580\left(\mathrm{mg} \mathrm{g}^{-1}\right)$ and followed the order: $\mathrm{Cr}>\mathrm{Pb}>\mathrm{Cd}$. This adsorption sequence can be associated with the characteristic of each metal and the form of interaction with the adsorbent.

Despite $\mathrm{Pb}$ and $\mathrm{Cr}$ have higher $\mathrm{K}_{\mathrm{f}}$ values (adsorption capacity) compared to $\mathrm{Cd}$, these elements showed lower reactivity $(\mathrm{n})$ over it $(\mathrm{Cd}>\mathrm{Pb}>\mathrm{Cr})$. The parameter " $n$ " indicates the reactivity of the adsorbent's active sites, in the linearization by Freundlich.

Thus, analyzing this parameter shown in Table 1 , it can be seen that the processes of $\mathrm{Cd}$ adsorption on the adsorbent are shown favorable. According to Sodré et al. (2001), values above 1 for this parameter are a strong indication of the presence of highly energetic sites, su ggesting that they were the first to be occupied by the metal, resulting in high energy interaction and high reactivity.

In the Langmuir linearization, it was verified that $\mathrm{Cr}$ had a higher adsorption capacity $\left(\mathrm{Q}_{\mathrm{m}}\right)$ compared to $\mathrm{Cd}$ and $\mathrm{Pb}$; however, comparing the parameter ' $b$ ', Cd showed the highest binding energy with the adsorbent.

According to Sharma et al. (2006), the aqueous solution containing the seeds byproduct of Moringa oleifera Lam. is a heterogeneous mixture containing various functional groups, especially low molecular weight amino acids. These amino acids can be considered an active group of binding agents,

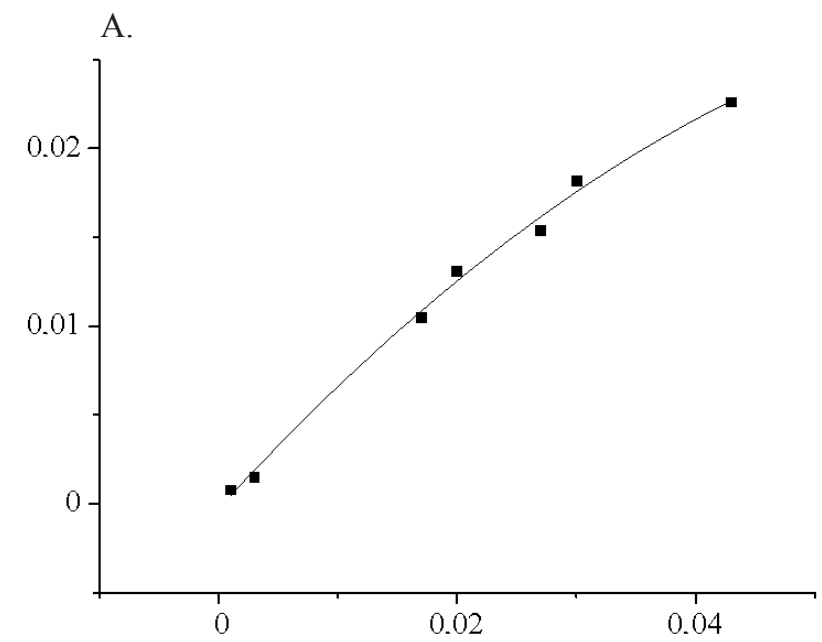

B.
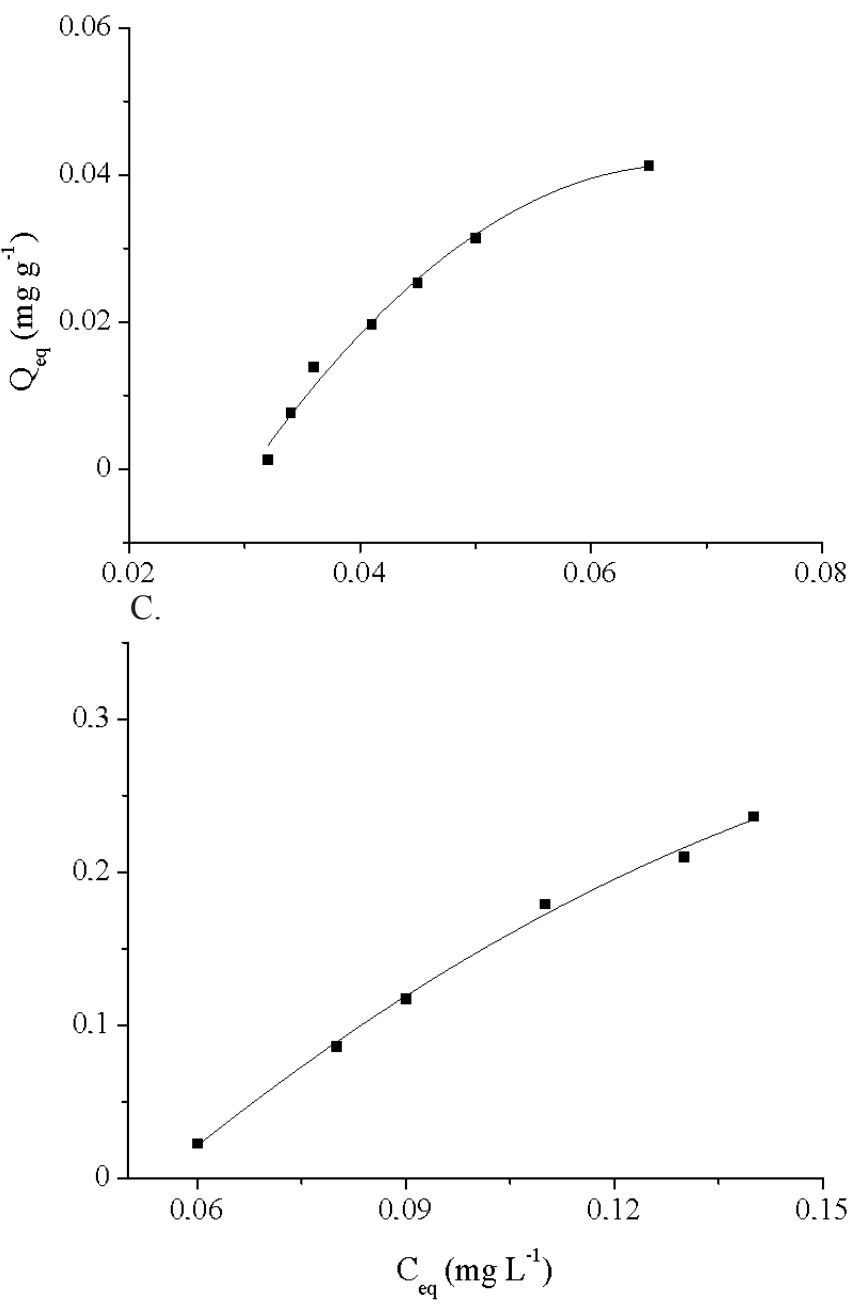

Figure 2. Adsorption isotherms of $\mathrm{Cd}(\mathrm{A}), \mathrm{Pb}(\mathrm{B})$ and $\mathrm{Cr}(\mathrm{C})$ on the Moringa oleifera Lam. byproduct

Table 1. Parameters of the equilibrium isotherm of Langmuir and Freundlich models for $\mathrm{Cd}, \mathrm{Pb}$ and $\mathrm{Cr}$ adsorption on the moringa byproduct

\begin{tabular}{|c|c|c|c|c|c|c|}
\hline \multirow{2}{*}{ Metal } & \multicolumn{3}{|c|}{ Langmuir model } & \multicolumn{3}{|c|}{ Freundlich model } \\
\hline & $q_{m}\left(m g g^{-1}\right)$ & b $\left(\mathrm{L} \mathrm{mg}^{-1}\right)$ & $\mathrm{R}^{2}$ & $\mathrm{~K}_{f}\left(\mathrm{mg} \mathrm{g}^{-1}\right)$ & n & $\mathrm{R}^{2}$ \\
\hline $\mathrm{Cd}$ & 0.02 & 1443.00 & 0.98 & 0.19 & 1.46 & 0.98 \\
\hline $\mathrm{Pb}$ & 0.01 & -30.77 & 0.89 & 8.98 & 0.57 & 0.95 \\
\hline $\mathrm{Cr}$ & 0.38 & -20.45 & 0.99 & 9.58 & 0.54 & 0.98 \\
\hline
\end{tabular}


acting even at low concentrations due to the ability to interact with metal ions increasing their sorption.

In multielementar solutions, there may be a decrease in the adsorption ability of a specific metal, compared to that of the same metal in monoelementar solutions. This decrease can be attributed to fewer active sites available, i.e., binding sites competitively are divided among metals present in the solution (Sharma et al., 2007), which was observed by the same author in studies using seeds of Moringa oleifera Lam. in a ternary solution containing $\mathrm{Cd}, \mathrm{Cr}$ and $\mathrm{Ni}$, whose adsorption values decreased by about 10 to $20 \%$ compared to the adsorption using a monoelementar solution.

Some factors related to electronegativity, hydrolysis constant and ionic radius can favor the adsorption of a metal species over another (Mimura et al., 2010). Regarding the electronegativity, there is the following selectivity order: $\mathrm{Pb}$ $>\mathrm{Cr}>\mathrm{Cd}$, since the higher the electronegativity, the greater the affinity for sorption (Sag et al., 2002). Regarding the ionic radius, $\mathrm{Pb}$ would be the most adsorbed, followed by $\mathrm{Cd}$ and $\mathrm{Cr}$. $\mathrm{Pb}$ ions have the smallest radius compared to the other metals studied, thus, it has greater accessibility to the surface and pores of the adsorbent, resulting in higher adsorption capacity (Srivastava et al., 2008).

However, in the present study it was observed that $\mathrm{Cr}$ ion was preferentially adsorbed over other metal species, this fact may be related to its higher positive charge and ease to form hydrolyzed species, which has a significant effect on the adsorption. The trend to undergo hydrolysis has been observed as the most important factor in adsorption processes involving several metal ions simultaneously (Lesmana et al., 2009). The element with the least ability to undergo hydrolysis is $\mathrm{Cd}$, followed by $\mathrm{Pb}$ and $\mathrm{Cr}$. However, the results showed that $\mathrm{Cd}$ was more adsorbed than $\mathrm{Pb}$. This can be explained by the Cd larger reactivity (n) of the active sites of the adsorbent, as shown in Table 1.

In addition to the aforementioned properties, the concentration factor can also be taken into account, since the metals were added to the solution at different concentrations and therefore an order of preference cannot be established regarding adsorption selectivity, as the $\mathrm{Cr}$ was added to the solution in excess, compared to the other metals.

\section{Conclusions}

1. The adsorption process occurred more efficiently at $\mathrm{pH}$ 5.0 , its use being feasible as an adsorbent in natural waters that typically have a $\mathrm{pH}$ between 5.0 and 5.5.

2. The experimental data of cadmium adsorption on the moringa byproduct were similar in both the models used, indicating a possible existence of more than one type of adsorption site interacting with the metal. Freundlich was the model that best fitted for lead. For chromium, data linearization showed a best fit by the Langmuir model.

3. The moringa byproduct can be considered an alternative for remediation of waters contaminated with toxic heavy metals cadmium, lead and chromium, being a low cost option which requires no previous treatment.

\section{AcKNOWLEDGEMENTS}

The authors would like to thank the Araucaria Foundation - SETI/PR for funding, through the Research Productivity Scholarship. Thanks are also due to $\mathrm{CNPq} / \mathrm{MCT}$ for funding through the project REPENSA.

\section{LITERATURE CITED}

AOAC - Association of Official Agriculture Chemists. Official methods of analysis, 18.ed., Maryland: AOAC, 2005. 3000p.

Araújo, W. S.; Amaral Sobrinho, N. M. B.; Mazur, N.; Gomes, P. C. Relação entre adsorção de metais pesados e atributos químicos e físicos de classes de solo do Brasil. Revista Brasileira de Ciência do Solo, v.26, p.17-27, 2002.

Brasil. Ministério da Saúde. Secretaria de Vigilânica em Saúde. Coordenação-Geral de Vigilância em Saúde Ambiental. Portaria MS n. ${ }^{\circ}$ 518/2004 - Brasília: Ministério da Saúde. 2004. 16p.

Camargo, O. A.; Alleoni, L. R. F.; Berton, R. S. O solo e a qualidade do ambiente. In: Andrade, J. C.; Abreu, M. F. (ed.). Análise química de resíduos sólidos para monitoramento e estudos agroambientais. Campinas: Instituto Agronômico, 2006, p.11-32.

Ekmekyapar, F.; Aslan, A.; Kemal Bayhan, Y.; Cakici, A. Biosorption of copper(II) by non-living lichen biomass of Cladonia rangiformis hoffm. Journal of Hazardous Materials, v.137, p.293-298, 2006.

Fetter, C.W. Contaminant hydrogeology. New York: Macmillan Publishing Company, 1993. 458p.

Gonçalves Jr., A. C.; Luchese, E. B.; Lenzi, E. Avaliação da fitodisponibilidade de cádmio, chumbo e cromo, em soja cultivada em Latossolo Vermelho Escuro tratado com fertilizantes comerciais. Química Nova, v.23, p.173-177, 2000.

Gonçalves Jr., A. C.; Pessoa, A. C. S. Fitodisponibilidade de cádmio, chumbo e cromo, em soja cultivada em Argissolo Vermelho eutroférrico a partir de adubos comerciais. Scientia Agraria, v.3, p.19-23, 2002.

Gonçalves Jr., A. C.; Selzlein, C.; Nacke, H. Uso de biomassa seca de aguapé (Eichornia crassipes) visando à remoção de metais pesados de soluções contaminadas. Acta Scientiarum. Technology, v.31, p.103-108, 2009.

IUPAC - International Union Pure and Applied Chemistry. Standard methods for the analysis of oils, fats and derivatives: Method 1121. In: Paquot C., Haufenne A. (ed.). Determination of moisture and volatiles matter content. Oxford: Blackwell, 7th ed, 1988. p.13-16.

Jahn, S. A. A. Proper use Moringa oleifera for food and water purification - selection of clones and growing of annual short-stem. Pflanzenzucht, v.4, p.22-25, 1989.

Katayon, S.; Noor, M. J. M. M.; Asma, M.; Ghani, L. A. A.; Thamer, A. M.; Azni, I.; Ahmad, J.; Khor, B. C.; Suleyman, A. M. Effects of storage conditions of Moringa oleifera seeds on its performance in coagulation. Bioresource Technology, v.97, p.1455-1460, 2006. 
Kumar, A.; Rao, N. N.; Kaul, S. N. Alkali-treated straw and insoluble straw xanthate as low cost adsorbent for heavy metal removal-preparation, characterization and application. Bioresource Technology, v.71, p.133-142, 2000.

Lesmana, S. O.; Febriana, N.; Soetaredjo, F. E.; Sunarso, J.; Ismadji, S. Studies on potential applications of biomass for the separation of heavy metals from water and wastewater. Biochemical Engineering Journal, v.44, p.19-41, 2009.

Mimura, A. M. S.; Vieira, T. V. A.; Martinelli, P. B.; Gorgulho, H. F. Aplicação da casca de arroz na adsorção dos íons $\mathrm{Cu}^{2+}$, $\mathrm{Al}^{3+}, \mathrm{Ni}^{2+}$ e $\mathrm{Zn}^{2+}$. Química Nova, v.33, p.1279-1284, 2010.

Oliveira, J. A.; Cambraia, J.; Cano, M. A. Absorção e acúmulo de cádmio e seus efeitos sobre o crescimento relativo de plantas de aguapé e salvínia. Revista Brasileira de Fisiologia Vegetal, v.13, p.329-341, 2001.

Peña-Rodríguez, S.; Fernández-Calviño, D.; Nóvoa-Muñoz, J. C.; Arias-Estévez, M.; Núñez-Delgado, A.; FernándezSanjurjo, M. J.; Álvarez-Rodríguez, E. Kinetics of Hg (II) adsorption and desorption in calcined mussel shells. Journal of Hazardous Materials, v.180, p.622-627, 2010.

Reddy, D. H. K.; Seshaiah, K.; Reddy, A. V. R.; Rao, M. M.; Wang, M. C. Biosorption of $\mathrm{Pb}^{2+}$ from aqueous solutions by Moringa oleifera bark: Equilibrium and kinetic studies. Journal of Hazardous Materials, v.174, p.831-838, 2010.

Sag, Y.; Akeael, B.; Kutsal, T. Ternary biosorption equilibria of $\mathrm{Cr}$ (VI), Cu (II) and Cd (II), on Rhizopus arrihzus. Separation Science and Technology, v.37, p.279-309, 2002.

Santos, V. C, G.; De Souza, J. V. T. M.; Tarley, C. R. T.; Caetano, J.; Dragunski, D. C. Copper ions adsorption from aqueous médium using the biosorbent sugarcane bagasse in natura and chemically modified. Water, Air and Soil Pollution, v. 216, p. 351-359, 2010a.

Santos, V. C. G. dos; Tarley, C. R. T.; Caetano, J.; Dragunski, D. C. Assessment of chemically modified sugarcane bagasse for lead adsorption from aqueous medium. Water Science \& Technology, v.62, p.457-465, 2010 b.
Sodré, F. F.; Lenzi, E.; Costa, A. C. Utilização de modelos físico-químicos de adsorção no estudo do Comportamento do cobre em solos argilosos. Química Nova, v.24, p.324330, 2001.

Sharma, P.; Kumari, P.; Srivastava, M. M.; Srivastava, S. Removal of cadmium from aqueous system by shelled Moringa oleifera Lam. Seed powder. Bioresource Technology, v.97, p.299-355, 2006.

Sharma, P.; Kumari, P.; Srivastava, M. M.; Srivastava, S. Ternary biosorption studies of Cd (II), $\mathrm{Cr}$ (III) and $\mathrm{Ni}$ (II), on shelled Moringa oleifera seeds. Bioresource Technology, v.98, p.474-477, 2007.

Srivastava, V. C.; Mall, I. D.; Mishra, I. M. Antagonistic competitive equilibrium modeling for the adsorption of ternary metal ions mixtures onto bagasse fly ash. Industrial \& Engineer. Chemistry Research, v.47, p.3129-3137, 2008.

Sud, D.; Mahajan, G.; Kaur, M. P. Agricultural waste material as potential adsorbent for sequestering heavy metal ions from aqueous solutions - A review. Bioresource Technology, v.99, p.6017-6027, 2008.

Tagliaferro, G. V.; Pereira, P. H. F.; Rodrigues, L. A.; Silva, M. L. C. P. Adsorção de chumbo, cádmio e prata em óxido de nióbio $(\mathrm{V})$ hidratado preparado pelo método da precipitação em solução homogênea. Química Nova, v.34, p.101-105, 2011.

Tarley, C. R. T.; Arruda, M. A. Z. Adsorventes naturais: Potencialidades e aplicações da esponja natural (Luffa cylindrica) na remoção de chumbo em efluentes de laboratório. Analytica, v.4, p.25-31, 2003.

Wang, L.; Zhang, J.; Wang, A. Removal of methylene blue from aqueous solution using chitosan- $g$-poly (acrylic acid)/ montmorillonite superadsorbent nanocomposite. Colloids and Surfaces A: Physicochemical and Engineering Aspects, v.322, p.47-53, 2008.

Welz, B.; Sperling, M. Atomic absorption spectrometry, 2.ed., Weinheim: Wiley-VCH, 1999.941p. 